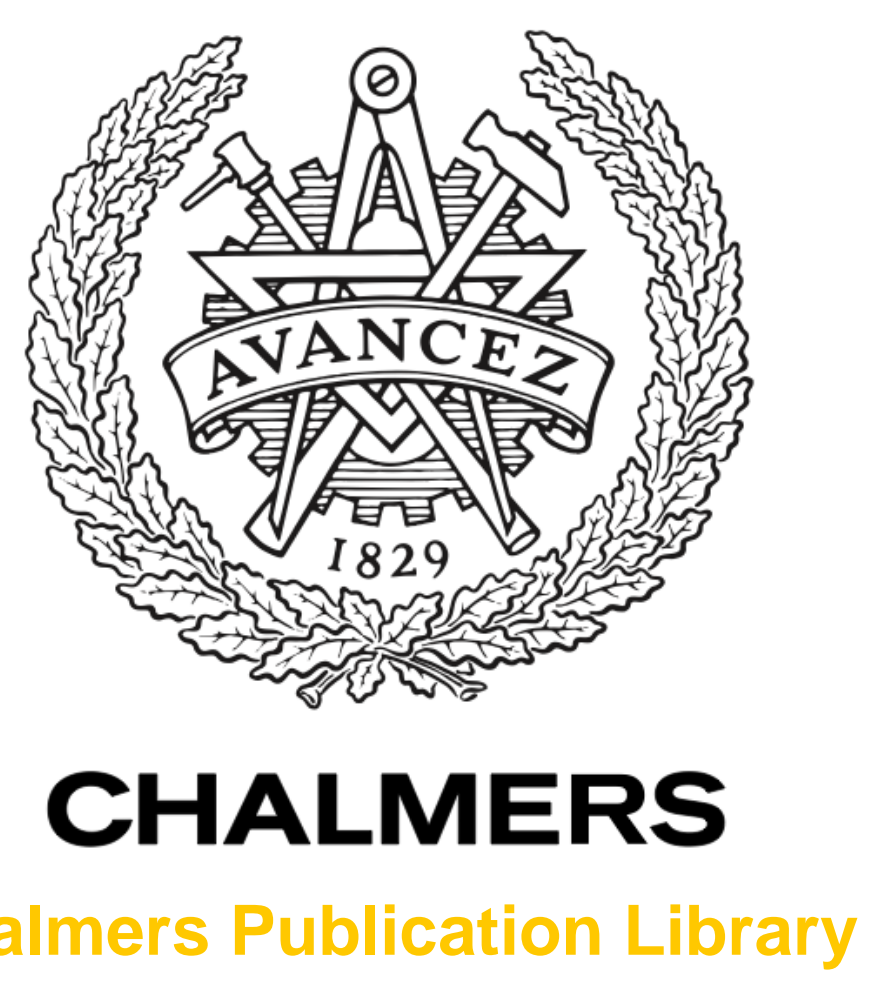

Chalmers Publication Library

The value of sharing planning information in supply chains

This document has been downloaded from Chalmers Publication Library (CPL). It is the author's version of a work that was accepted for publication in:

International Journal of Physical Distribution \& Logistics Management (ISSN: 0960-0035)

Citation for the published paper:

Jonsson, P. ; Mattsson, S. (2013) "The value of sharing planning information in supply

chains". International Journal of Physical Distribution \& Logistics Management, vol. 43(4),

pp. 282-299.

http://dx.doi.org/10.1108/IJPDLM-07-2012-0204

Downloaded from: http://publications.lib.chalmers.se/publication/176432

Notice: Changes introduced as a result of publishing processes such as copy-editing and formatting may not be reflected in this document. For a definitive version of this work, please refer to the published source. Please note that access to the published version might require a subscription.

Chalmers Publication Library (CPL) offers the possibility of retrieving research publications produced at Chalmers University of Technology. It covers all types of publications: articles, dissertations, licentiate theses, masters theses, conference papers, reports etc. Since 2006 it is the official tool for Chalmers official publication statistics. To ensure that Chalmers research results are disseminated as widely as possible, an Open Access Policy has been adopted.

The CPL service is administrated and maintained by Chalmers Library. 
Full reference to this article: Jonsson, P. and Mattsson, S-A. (2013). "The value of sharing planning information in supply chains”. International Journal of Physical Distribution and Logistics Management, Vol. 43, No. 4, pp. 282-299. DOI: http://dx.doi.org/10.1108/IJPDLM-07-2012-0204

\title{
The value of sharing planning information in supply chains
}

\author{
Patrik Jonsson \& Stig-Arne Mattsson \\ Department of Technology Management \& Economics \\ Chalmers University of Technology, Gothenburg, Sweden \\ E-mail: Patrik.jonsson@chalmers.se
}

\section{Introduction}

Sharing only order-based demand information between supply chain partners gives a delayed and distorted picture of customers' real demand (Småros et al., 2003). It also tends to increase the demand variability and accordingly the need for safety stock (Forrester, 1961). More accurate, future-oriented and planning-related demand information, such as point-of-sales data, forecasts, planned orders, and customer stock balances, is often available from the customer. If the supplier is able to access and use such information in its planning processes, it may have opportunities to improve customer service and reduce the capital tied up in inventory.

To benefit from future-oriented information, we need to understand the value of sharing the different types of planning information in various contexts. The literature on information sharing has examined specific types of information in contexts with different levels of uncertainty, but has produced differing and often conflicting conclusions regarding the value of information sharing in supply chains (see Ketzenberg et al., 2007). Information sharing is also studied in relation to collaborative planning and supply chain integration, but this literature does not explain the value of information sharing, because this is part of larger concepts and because various information types and contexts are studied (e.g. Skjoett-Larsen et al., 2003; Zhou and Benton, 2007; Flynn et al., 2010).

We thus agree with Sahin and Robinson (2002) that the research literature lacks consistent conclusions and a systematic framework to explain which type of planning information should be shared in different supply chains. Thus, although information technology has made information sharing easier, managers should not assume that more information automatically implies better performance. The type and level of uncertainty, coupled with the specific type and use of planning information, will determine whether information sharing really provides value. This paper aims to close some gaps in the information sharing literature regarding how and when to share different types of planning information in supply chains. It will also close gaps in the wider collaborative planning and supply chain integration literature by relating the significance of various planning information types to contextual dimensions. Specifically, it will use a simulation approach to examine the consequences for capital tied up in inventory of sharing four different types of planning information (point-of-sales data, customer forecasts, stock-on-hand data, and planned orders) when using re-order point (R,Q) methods in a distribution network. The simulation parameters correspond to situations with medium to high customer order frequency and two-tier supply chains with relatively short lead times. The next 
Full reference to this article: Jonsson, P. and Mattsson, S-A. (2013). "The value of sharing planning information in supply chains”. International Journal of Physical Distribution and Logistics Management, Vol. 43, No. 4, pp. 282-299. DOI: http://dx.doi.org/10.1108/IJPDLM-07-2012-0204

sections define information types, review previous literature, outline the research model and the simulation set-up. Thereafter, the simulation results are presented and discussed, and conclusions drawn.

\section{Literature review}

\section{The concept of information sharing}

Access to information residing in another company in the supply chain has been spoken of in terms of information sharing and visibility. Information sharing is an activity while visibility is a potential outcome of information sharing that leads to more effective supply chain (Barratt and Oke, 2007).

The concept of information sharing may be used when speaking of access to information about the exact physical location of goods en route from supplier to customer at a particular moment. This can be tracked using such things as radio frequency identification (RFID) and bar code applications. However, information sharing can also be used with reference to access information that can be used to improve the management of material flows, here called planning information. Planning information may be either demand-related or supply-related. The type of demand-related planning information shared between customers and suppliers includes customer orders, point-of sales data, forecasts, planned orders and available customer stock. Examples of supply-related planning information include availability of supplier stock, lead times, deliveries expected to be delayed, and advanced shipment notices. This paper deals only with demand-related planning information used to improve inventory management.

Most studies on the value of sharing different planning information types are analytical (e.g. Lee et al., 2000, Cachon and Fisher, 2000) or simulation-based (e.g. Croson and Donohue, 2003), but there are also a few surveys (e.g. Forslund and Jonsson, 2007; Sezen, 2008). See Huang et al. (2003) and Ketzenberg et al. (2007) for information sharing literature reviews. Information sharing is also embedded in the wider concepts of collaborative planning or collaborative planning forecasting and replenishment (CPFR) and supply chain integration. Seifert (2003) defines CPFR as an initiative among all participants in the supply chain intended to improve the relationship among them through jointly managed planning processes and shared planning information. Most types of demand planning information may be shared in CPFR (Skjoett-Larsen et al., 2003; Danese, 2007). Flynn et al. (2010) define supply chain integration as the degree to which a manufacturer strategically collaborates with its supply chain partners and collaboratively manages intra- and inter-organisation processes. Supply chain integration contains three dimensions: customer, supplier and internal integration. Customer and supplier integration deals with the interaction with external partners to design inter-organisational strategies, practices and activities into synchronised collaborative processes (Stank et al., 2001). It includes communication and interaction at a strategic level, information system capabilities, collaborative planning activities, and sharing planning information. Different mixes of demand-related planning information types are included in customer integration constructs (Frohlich and Westbrook, 2001; Devaraj, 2007; Zhou and Benton, 2007; Flynn et al., 2010).

\section{Types of planning information related to inventory management}

The literature on information sharing, collaborative planning, CPFR, and supply chain integration stresses the importance of sharing and using point-of-sales data, customers' own 
Full reference to this article: Jonsson, P. and Mattsson, S-A. (2013). "The value of sharing planning information in supply chains”. International Journal of Physical Distribution and Logistics Management, Vol. 43, No. 4, pp. 282-299. DOI: http://dx.doi.org/10.1108/IJPDLM-07-2012-0204

forecasts, customers' stock on hand information, and customer-generated planned orders. Sharing these four types of demand planning information are supposed to benefit inventory management.

Point-of-sales data (POS) are reports on customers' sales that are periodically forwarded to the supplier. The supplier uses this historical demand data to forecast future demand. The data represent real demand to a greater extent than customer orders (e.g. Forrester, 1961).

Customers' own forecasts of future demand enable the supplier to base its inventory replenishment decisions directly on the customers' estimates of future demand rather than on forecasts from historical sales figures.

Stock-on-hand information is useful for planning because in the short run a customer's demand is not just a consequence of its own customers' demand but also of the current quantity it holds in stock. The larger the quantity in stock, the less the net demand will be on the supplier compared to the gross demand for the customer.

Customer-generated planned replenishment orders represent a combination of the two previous types of planning information, since planned orders represent the result of the customers' forecasts as well as their stock-on-hand. The time frame for this information should correspond to at least the replenishment lead time for the supplier.

\section{The value of sharing different types of planning information}

The literature shows mixed results regarding the effect of information sharing on performance because research studies have involved different types of information sharing. Studies indicate that sharing and using point-of-sales data is not always the best solution. Gilbert (2005) shows that point-of-sales data is not more valuable than order history when the demand variation is caused by a true demand shift. Williams and Waller (2010) conclude that point-of-sales data in general outperforms order history data as an input to forecasting. Lee et al. (2000) suggest that the underlying demand process and the lead times have a significant impact on the magnitude of inventory reductions associated with sharing point-of-sales data. Larger reductions and greater savings for the supplier are achieved when the demand correlation over time is high, the demand variance within each period is high, or the lead times are long. Croson and Donohue (2003) argue that the benefits of point-of-sales data are less clear when the demand distribution is stable compared to settings where the demand distribution is unknown to the supplier and non-stationary. Cachon and Fisher (2000) conclude that the benefits of more frequent ordering and timely processing outweigh the benefits of sharing point-of-sales data for stationary demand. The limited value of sharing point-of-sales data is explained by noticing that a customer's demand information is most valuable when its inventory approaches a level that should trigger the supplier to order additional inventory, which is also exactly when the customer is likely to release a replenishment order.

There are several studies related to the value of sharing forecast information. Forslund and Jonsson (2007) and Sezen (2008) did not show any general performance effect of sharing forecasts. Lee et al. (2000) argue that sharing forecast information is especially beneficial in dynamic situations with non-stationary demand and systematic trends. Aviv (2001), Kaipia and Hartiala (2006) and Mishra et al. (2009) conclude that sharing forecast information is more valuable if the variance in demand is high, the customers' forecasts are more reliable than the supplier's, and the correlation between forecasts is low. Angulo et al. (2004) conclude that sharing forecasts should primarily be applied to products with non-stationary 
Full reference to this article: Jonsson, P. and Mattsson, S-A. (2013). "The value of sharing planning information in supply chains”. International Journal of Physical Distribution and Logistics Management, Vol. 43, No. 4, pp. 282-299. DOI: http://dx.doi.org/10.1108/IJPDLM-07-2012-0204

demand such as new products, products facing new competitors, and products often promoted.

Sharing stock-on-hand information means that not only the supplier's own inventory levels are considered, but also the customers' inventory levels when the supplier releases new replenishment orders (i.e. the echelon stock for the supplier is compared with the re-order point, not only with stock-on-hand). Axsäter and Rosling (1993) have proved that in general using echelon stock policies in two-level distribution systems with stationary probabilistic demand is superior to installation stock policies only using local stock-on-hand information. No study trying to quantify these benefits has been found in the literature. Studies on vendormanaged inventory (e.g. Aviv, 2001; Vigtil, 2007) have shown positive effects of sharing inventory-level information. However, Cachon and Fisher (2000) found that using traditional orders leads to almost equally good results if orders are placed frequently enough and demand is stationary.

\section{The value of information sharing in different contexts}

Another reason for differing opinions on the value of information sharing is that contextual variables affect information uncertainty. The demand pattern and the distribution network (i.e. number and sizes of customers, order batch size, and supply lead time) may have a mediating effect on the value of information sharing:

Several of the studies cited above show the impact of demand variability on the value of information sharing. Some relate to sharing specific types of information, but the conclusions regarding demand patterns are general. Bourland et al. (1996), for example, show that inventory-related benefits are particularly sensitive to demand variability and the degree to which the order and production cycles are out of phase. Ahuhilal et al. (2006) found that the value of information sharing was minimal when the demand pattern was stationary, while its value was maximised with cyclical and highly variable demand patterns. Zhao and Xie (2002) showed that the forecast error distributions faced by retailers significantly influence the magnitudes of the cost savings from information sharing. The expected bias in forecast errors had a much more significant impact on supply chain performance and the value of information sharing than the standard deviation of forecast errors and its pattern of deterioration over time. A slight positive bias in the retailer's forecast increased the benefit of sharing information for the supplier and the entire supply chain. Chen (1998), on the other hand, showed that the value of information tends to increase as a result of increases in the number of stages, the lead times, or the batch sizes. Higher demand variability decreased the value of information, and extreme levels of customer service increased the value.

The distribution network (i.e. the number of retailers and suppliers) should also affect the value of information sharing. Moinzadeh (2002) showed that the value of information sharing decreases when the number of retailers increases. This is explained by the fact that the larger the number of retailers, the more the random variation in demand tends to even out, which reduces the value of information sharing. Using the same risk-pooling reasoning, the value of information sharing could be influenced by whether information is shared with only a limited number of a company's customers and not with the many small customers.

The value of information sharing should also be affected by the customer order batch size. The negative effects of not sharing information are normally high with large bullwhip effects, and the bullwhip effect is amplified by large batch sizes (Lee et al., 1997). Another negative effect of large customer order batch sizes may be delayed information sharing. However, Ketzenberg et al. (2007) emphasise that the batch sizing effect on information sharing is not 
Full reference to this article: Jonsson, P. and Mattsson, S-A. (2013). "The value of sharing planning information in supply chains”. International Journal of Physical Distribution and Logistics Management, Vol. 43, No. 4, pp. 282-299. DOI: http://dx.doi.org/10.1108/IJPDLM-07-2012-0204

necessarily linear. With very large batch sizes, the cycle stock proportion of the tied-up capital is large and the relative effect of reduced safety stock from information sharing will be small.

The supply lead times should also affect the value of information sharing, for example with longer lead times having a negative impact on the bullwhip effect (Chen et al., 2000). Lee et al. (2000) and Moinzadeh (2002) showed that the value of information increases as the ratio of the retailer's lead time to the overall supply lead time decreases. This is because a large part of the total safety stock is held at the supplier when the retailer's lead time is short.

The research variables and research model

The literature review showed that the value of information sharing varies for different information types and different inventory control methods. It is also clear that the demand pattern and distribution network, as well as the inventory control models and parameters, are important mediating variables. Different value definitions should also lead to different conclusions. Figure 1 summarizes the research variables and research model used in this study.

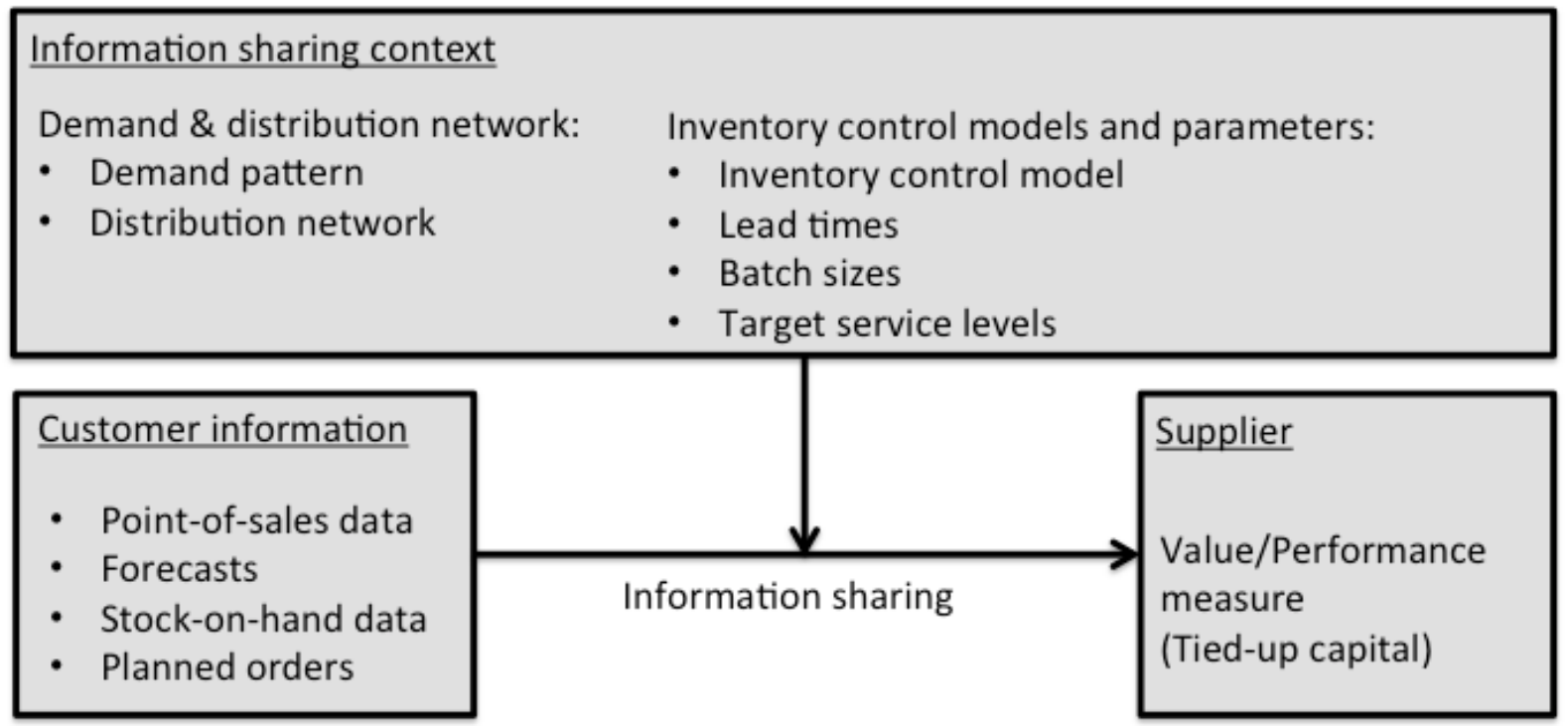

Figure 1. The research variables and research model

\section{Methodology and research design}

This analysis is based on a simulation study. The use of simulation in supply chain analysis is a rather obvious choice since discrete event simulation models can handle stochastic behaviour throughout the supply chain and thus phenomena dependent on uncertainties in operations can be evaluated (Persson and Olhager, 2002). A simulation approach is also necessary for studying cases with a mix of a few large customers with information sharing and several small customers without information sharing.

Information sharing context: Distribution networks

Six different distribution networks were studied. One contains three customers, one six, one nine, and one eighteen customers. All customers share information in these networks. In 
Full reference to this article: Jonsson, P. and Mattsson, S-A. (2013). "The value of sharing planning information in supply chains”. International Journal of Physical Distribution and Logistics Management, Vol. 43, No. 4, pp. 282-299. DOI: http://dx.doi.org/10.1108/IJPDLM-07-2012-0204

addition, two distribution networks containing a mix of information sharing and no information sharing customers were studied. These two distribution networks consist of nine customers for which the supplier has access to customer demand-related information and a number of small customers with whom no information sharing takes place. In one network the small customers represent $20 \%$ and in the other $40 \%$ of the total demand of the nine large customers together. These two distribution networks were included to analyse the value of sharing information only with the most important customers.

\section{Information sharing context: Demand scenarios}

For each of the six distribution networks, three demand scenarios with different demand patterns for the customers are analysed. The first scenario has a stationary and on average even demand with random variations. A stationary and even demand for the customers also means a stationary and even demand for the supplier.

The second scenario is characterised by seasonal and random variations in demand. The deseasonalised demand is thus an even demand on average. The demand is stationary, which implies that the seasonal indexes representing the seasonal variations remain unchanged over time.

In the third scenario, the customers also face an even demand on average with random variations during most parts of the year. However, they also carry out promotional activities twice a year, which periodically increase demand. This results in a non-stationary demand for the customers, and thus for the supplier as well. It is assumed that it is possible to anticipate the increase in demand by the customers since the promotional activities are planned. This is not the case for the supplier unless the customers share forecast information.

\section{Information sharing context: Demand data}

Demand per day for 24000 days (corresponding to 100 years) was randomly generated. As suggested by Bagchi et al. (1984), customer demand should be modelled as a compound distribution consisting of demand size and demand intensity. To accomplish this, demand per day for each customer was created using a combination of randomly generated numbers of customer orders from a Poisson distribution and randomly generated order quantities from a uniform distribution.

The demand from the small customers not sharing information with the supplier was modelled as a group and was assumed to be normally distributed. In the first case the normal distribution for the small customers was specified with an average equal to $20 \%$ of the average daily demand for the big nine customers together and a coefficient of variance equal to 0.3 . In the second case the small customer average was set at $40 \%$. Table 1 displays the number of customer orders and average demand per day used in the simulation. It also shows the resulting standard deviation per day for the customers in each group of three in the case of even demand. 
Full reference to this article: Jonsson, P. and Mattsson, S-A. (2013). "The value of sharing planning information in supply chains”. International Journal of Physical Distribution and Logistics Management, Vol. 43, No. 4, pp. 282-299. DOI: http://dx.doi.org/10.1108/IJPDLM-07-2012-0204

Table 1. Customer orders and daily demand per customer in a customer distribution netwo

\begin{tabular}{|l|c|c|c|}
\hline \multirow{2}{*}{ Parameters } & \multicolumn{3}{|c|}{ Customer } \\
\cline { 2 - 4 } & $\mathbf{1}$ & $\mathbf{2}$ & $\mathbf{3}$ \\
\hline Customer orders per day & 4 & 6 & 10 \\
\hline Customer order quantities & $1-5$ & $2-10$ & $3-15$ \\
\hline Average demand per day & 11.9 & 35.8 & 88.8 \\
\hline Standard deviation per day & 6.4 & 16.2 & 31.2 \\
\hline
\end{tabular}

Based on the stationary randomly generated demand per day, seasonal and promotional demand is created by multiplying the demand data with seasonal and promotional indexes, respectively (Figure 2). They are chosen so that these variations are not overrun by the random variations in the demand during lead time.

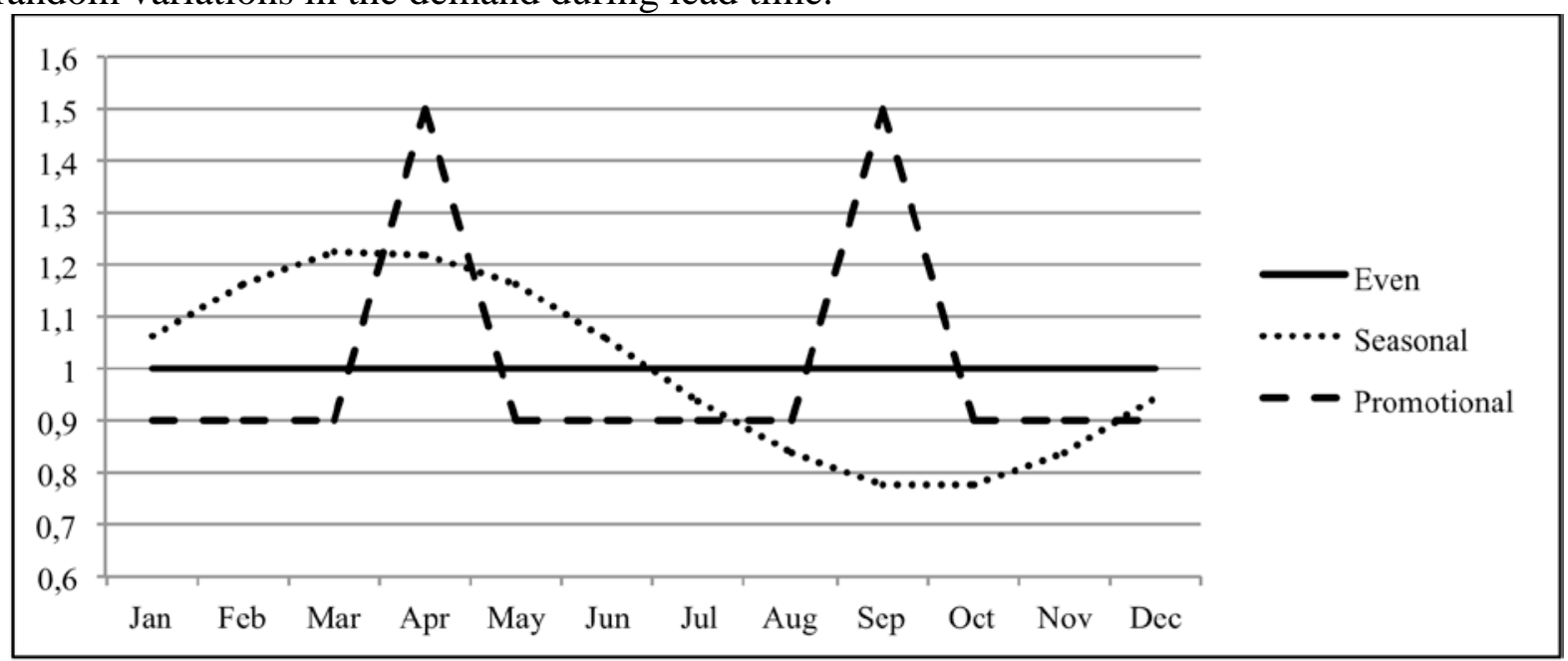

\begin{tabular}{|l|l|l|l|l|l|l|l|l|l|l|l|l}
\hline \multirow{2}{*}{ Index } & \multicolumn{10}{|c}{ Month } \\
\cline { 2 - 15 } & Jan & Feb & Mar & Apr & May & Jun & Jul & Aug & Sep & Oct & Nov & Dec \\
\hline Even index & 1.0 & 1.0 & 1.0 & 1.0 & 1.0 & 1.0 & 1.0 & 1.0 & 1.0 & 1.0 & 1.0 & 1.0 \\
\hline $\begin{array}{l}\text { Seasonal } \\
\text { index }\end{array}$ & 1.065 & 1.165 & 1.224 & 1.222 & 1.161 & 1.057 & 0.937 & 0.835 & 0.776 & 0.778 & 0.839 & 0.944 \\
\hline $\begin{array}{l}\text { Promotional } \\
\text { index }\end{array}$ & 0.9 & 0.9 & 0.9 & 1.5 & 0.9 & 0.9 & 0.9 & 0.9 & 1.5 & 0.9 & 0.9 & 0.9 \\
\hline
\end{tabular}

Figure 2. Even, seasonal and promotional demand indexes

\section{Inventory control models}

All customers use a re-order point $(\mathrm{R}, \mathrm{Q})$ system to generate replenishment orders to the supplier. Two different order quantities are used by the customers, one corresponding to five days and the other to ten days of average demand. These two order quantities are used to test the influence of bullwhip effects of large order quantities on information sharing. The safety stocks are calculated from a demand fill rate level of $98 \%$. 
Full reference to this article: Jonsson, P. and Mattsson, S-A. (2013). "The value of sharing planning information in supply chains”. International Journal of Physical Distribution and Logistics Management, Vol. 43, No. 4, pp. 282-299. DOI: http://dx.doi.org/10.1108/IJPDLM-07-2012-0204

The inventory control model for the supplier is also a re-order point (R,Q) system with a fixed order quantity corresponding to six days of average demand for all information sharing options as well as for the options based only on customer orders. The same customer orders are received irrespective of the information sharing method used. Table 2 summarizes the inventory control parameters, which are chosen to represent typical industry practices for retail distribution from a central warehouse.

Table 2. Inventory control parameters

\begin{tabular}{|l|l|l|}
\hline Parameters & Customer & Supplier \\
\hline Lead time & 2 days & 10 days \\
\hline Order quantity & 5 or 10 days' demand & 6 days' demand \\
\hline Service level (demand fill rate) & $98 \%$ & $98 \%$ \\
\hline
\end{tabular}

\section{Processing shared information}

In the case of no information sharing, the demand during lead time is derived from twelvemonth moving average forecasts calculated monthly. For the demand scenario with seasonal variation in demand, the historical demand is deseasonalised before applying the moving average calculations. Customer orders, point-of-sales data, stock-on-hand data, as well as planned orders are assumed to be communicated on a daily basis. Customer forecasts are communicated monthly (forecasts are usually revised only on a monthly basis).

When sharing point-of-sales data, the demand during lead time is forecast in basically the same way as for the case with no information sharing. The only difference is that the monthly moving average forecasts are based on summarised daily point-of-sales data from the customers instead of on the supplier's own historical deliveries. When the supplier gets monthly forecasts from the customers, the demand during lead time is based on the sum of these forecasts.

To benefit from sharing customers' daily stock-on-hand data to decide whether to order a replenishment, the supplier uses the echelon stock plus open orders instead of just its own stock-on-hand quantity and open orders.

Planned orders from customers are calculated by running daily material requirements planning for each customer over a period equal to the lead time for the supplier's replenishments. The sum of these planned orders represents an estimate of demand during lead time for the supplier and, in the case when sharing planned order information, is used as the forecast demand during the lead time part of the re-order point.

The way data received from the customers is processed is summarised in Table 3 for the various types of information sharing, except for the deseasonalizing and reseasonalizing demand data in the case with seasonal varying demand, and when forecasts are based on customer orders and point-of-sales. In the cases with small customers not sharing any information with the supplier, a twelve-month moving average forecast based on historic deliveries for the group as a whole is added to the forecast demand in column 4. 
Full reference to this article: Jonsson, P. and Mattsson, S-A. (2013). "The value of sharing planning information in supply chains”. International Journal of Physical Distribution and Logistics Management, Vol. 43, No. 4, pp. 282-299. DOI: http://dx.doi.org/10.1108/IJPDLM-07-2012-0204

Table 3. Summary of how data received from the customers for the various information sharing types is processed

\begin{tabular}{|l|l|l|l|}
\hline $\begin{array}{l}\text { Data received from } \\
\text { customers }\end{array}$ & $\begin{array}{l}\text { Processing received } \\
\text { data }\end{array}$ & $\begin{array}{l}\text { Forecasting demand } \\
\text { per month }\end{array}$ & $\begin{array}{l}\text { Forecasting demand } \\
\text { during lead time for } \\
\text { the re-order point }\end{array}$ \\
\hline Customer orders & $\begin{array}{l}\text { Calculating monthly } \\
\text { delivered quantities for } \\
\text { all customers }\end{array}$ & $\begin{array}{l}\text { Twelve-month moving } \\
\text { average from delivery } \\
\text { statistics }\end{array}$ & $\begin{array}{l}\text { Current month forecast } \\
\text { times the suppliers lead } \\
\text { time in months }\end{array}$ \\
\hline Forecasts & $\begin{array}{l}\text { Summarising monthly } \\
\text { forecasts from } \\
\text { customers }\end{array}$ & $\begin{array}{l}\text { Current month } \\
\text { summarised forecasts } \\
\text { times the suppliers lead } \\
\text { time in months }\end{array}$ \\
\hline Point-of-sales & $\begin{array}{l}\text { Summarising point-of- } \\
\text { sales data per running } \\
\text { month from all } \\
\text { customer }\end{array}$ & $\begin{array}{l}\text { Twelve-month moving } \\
\text { average from } \\
\text { summarised point-of- } \\
\text { sales data }\end{array}$ & $\begin{array}{l}\text { Current month forecast } \\
\text { times the suppliers lead } \\
\text { time in months }\end{array}$ \\
\hline Stock-on-hand data & $\begin{array}{l}\text { Calculating monthly } \\
\text { delivered quantities } \\
\text { from all customers }\end{array}$ & $\begin{array}{l}\text { Twelve-month moving } \\
\text { average from delivery } \\
\text { statistics }\end{array}$ & $\begin{array}{l}\text { Current month forecast } \\
\text { times the echelon lead } \\
\text { time in months }\end{array}$ \\
\hline Planned orders & $\begin{array}{l}\text { Summarising planned } \\
\text { orders from customers } \\
\text { over the suppliers' lead } \\
\text { time }\end{array}$ & $\begin{array}{l}\text { Summarised planned } \\
\text { orders }\end{array}$ & \\
\hline
\end{tabular}

\section{Simulation model and performance measurement}

As this paper focuses on inventory management, the relevant performance criteria are tied-up capital and customer service. The former is evaluated by measuring the tied-up capital at fixed service levels of the inventories when sharing and using information. The simulations were carried out in two steps. The first step is an event-driven simulation where issuing from stock, calculating net requirements, releasing new replenishment orders and replenishing stock from open orders are carried out on a daily basis for the customers, as well as for the supplier.

After each event-driven simulation, the service level reached was calculated and compared to the targeted service level of $98 \%$ demand fill rate. If the service level reached differed from the targeted service level, the re-order point was increased or decreased and a new eventdriven simulation was run. This iterative procedure continued until the targeted service level was reached.

The baseline for comparison was the average inventories in the simulation with no information sharing. The demand fill rate service and customer order quantity (5 and 10 days' average demand, respectively) were the same. Standard deviations for the annual average inventory levels were calculated to allow testing for the significance of achieved differences.

\section{Analysis and discussion}

The data in Tables 4 to 6 present the results in the case when customer order quantities correspond to five days' average demand. The changes in inventory levels of the various types of information sharing are compared to the baseline scenario without information sharing. 
Full reference to this article: Jonsson, P. and Mattsson, S-A. (2013). "The value of sharing planning information in supply chains”. International Journal of Physical Distribution and Logistics Management, Vol. 43, No. 4, pp. 282-299. DOI: http://dx.doi.org/10.1108/IJPDLM-07-2012-0204

Corresponding results when ten days’ order quantities are presented in Appendix A. Bold print indicates that mean changes are significant ( $p<0.05$ level) compared to the baseline.

\section{Demand scenario 1: Even demand}

The results for the demand scenario when customers have an even demand with random variations and five days' order quantities (Table 4) show that no significant change in average inventory is achieved by allowing the supplier to access customers' forecasts or point-of-sales data. This can be expected since the demand to the supplier is stationary; with only minor loss of accuracy it can be derived from the supplier's own delivery statistics. This result supports the findings made by Croson and Donohue (2003) concerning sharing point-of-sales data and Angulo et al. (2004) concerning sharing forecasts.

Table 4. Changes in capital tied up in inventory in per cent for various information types (Even demand and customer replenishment order quantities $=5$ days' average demand)

\begin{tabular}{|l|c|c|c|c|c|c|}
\hline \multirow{2}{*}{$\begin{array}{l}\text { Type of shared } \\
\text { information }\end{array}$} & \multicolumn{6}{|c|}{ Number of customers in the distribution network } \\
\cline { 2 - 7 } & 3 & 6 & 9 & 18 & $9+20 \%$ & $9+40 \%$ \\
\hline Forecast & -0.2 & -0.5 & -0.1 & -0.1 & -0.1 & 0.0 \\
\hline Point-of-sales & 0.0 & -0.3 & 0.1 & -0.1 & -0.1 & 0.1 \\
\hline Stock-on-hand & $\mathbf{- 1 7 . 5}$ & $\mathbf{- 9 . 6}$ & $\mathbf{- 6 . 2}$ & $\mathbf{- 6 . 3}$ & $-\mathbf{5 . 1}$ & $-\mathbf{3 . 4}$ \\
\hline Planned orders & $\mathbf{3 . 2}$ & $\mathbf{4 . 4}$ & $\mathbf{6 . 5}$ & $\mathbf{6 . 9}$ & $\mathbf{5 . 2}$ & $\mathbf{3 . 5}$ \\
\hline
\end{tabular}

Note: The figures represent changed inventory level mean values (in percentage) compared to the baseline scenario without information sharing. Bold means are significantly different $(\mathrm{p}<0.05)$ compared to the baseline scenario without information sharing.

Contrary to these results, significant changes in average inventory are achieved for all six distribution networks when stock-on-hand data and planned orders are shared. These results indicate that an important reduction in average inventory can be achieved by letting the supplier share the customers' stock-on-hand data. The findings also clearly show that the potential reduction in average inventory decreases as the number of customers increases.

Opposite changes in inventory levels are seen when customers allow the supplier access to information about planned orders. The average inventory increases significantly for all six types of distribution networks (Table 4). This may seem strange since this approach to information sharing means that the replenishment order quantities planned by the customers replace the supplier's own forecast when calculating the demand during lead time, and that accordingly the customers' stock-on-hand quantities are considered. In addition, the advantage of using material requirements planning in distribution networks has been pointed out by several authors (e.g. Martin, 1983, p 40; Fogarty et al., 1991, p. 313). Material requirements planning principles are, however, also known for generating upstream variations in demand, so-called system nervousness (van Donselaar and Gubbels, 2002), created by the Burbidge type of bullwhip effects (Burbidge, 1991). This explains the results displayed in Table 4, since a re-order point that is too high results in an increase in inventory that is bigger than a decrease in inventory due to a corresponding order point that is too low. The reason is that negative inventories when shortages occur are considered as zero inventories, and negative inventories occur more often when re-order points are too low. A way to overcome these variations in estimated demand during lead time from planned orders is to freeze the orders during the supplier's replenishment lead time. This influences the size of the customers' safety stock and is outside the scope of this research. 
Full reference to this article: Jonsson, P. and Mattsson, S-A. (2013). "The value of sharing planning information in supply chains”. International Journal of Physical Distribution and Logistics Management, Vol. 43, No. 4, pp. 282-299. DOI: http://dx.doi.org/10.1108/IJPDLM-07-2012-0204

The results when the customers' replenishment order quantities are ten days' average demand are shown in Appendix A (Table A.1). As in the case with smaller replenishment quantities, no changes in inventory levels are found when customers' forecasts and point-of-sales data are shared. Inventories when sharing stock-on-hand data are, however, significantly reduced. A comparison of Tables 4 and Appendix A.1 also shows that the reduction in inventory becomes much bigger when the customer replenishment order quantities are bigger. The result supports Moinzadeh's (2002) statement that echelon policies are more attractive with large replenishment order quantities. The increase in inventory levels when sharing information about planned orders is basically the same as the case with smaller replenishment orders.

\section{Demand scenario 2: Seasonal varying demand}

As in the scenario with even demand, no reduction in average inventory is achieved by sharing point-of-sales data and customer forecasts (Table 5 and Appendix A, Table A.2). This is as expected since the seasonal varying demand for the supplier is stationary. This result thus supports the findings of Croson and Donohue (2003) as well as Angulo et al. (2004).

Table 5. Changes in capital tied up in inventory in per cent for various information types (Seasonal demand and customer replenishment order quantities $=5$ days' average demand)

\begin{tabular}{|l|c|c|c|c|c|c|}
\hline \multirow{2}{*}{$\begin{array}{l}\text { Type of shared } \\
\text { information }\end{array}$} & \multicolumn{6}{|c|}{ Number of customers in the distribution network } \\
\cline { 2 - 7 } & 3 & 6 & 9 & 18 & $9+20 \%$ & $9+40 \%$ \\
\hline Forecast & 1.6 & -0.5 & -0.2 & -0.6 & -0.5 & -0.6 \\
\hline Point-of-sales & 1.9 & -0.5 & -0.4 & -0.3 & -0.4 & -0.5 \\
\hline Stock-on-hand & $\mathbf{- 1 4 . 7}$ & $\mathbf{- 1 0 . 2}$ & $\mathbf{- 9 . 1}$ & $\mathbf{- 8 . 6}$ & $\mathbf{- 8 . 3}$ & $-\mathbf{6 . 1}$ \\
\hline Planned orders & $\mathbf{2 2 . 5}$ & $\mathbf{3 2 . 3}$ & $\mathbf{3 3 . 3}$ & $\mathbf{3 3 . 5}$ & $\mathbf{3 9 . 4}$ & $\mathbf{3 9 . 7}$ \\
\hline
\end{tabular}

Note: The figures represent changed inventory level mean values (in percentage) compared to the baseline scenario without information sharing. Bold means are significantly different $(\mathrm{p}<0.05)$ compared to the baseline scenario without information sharing.

Table 5 shows a significant reduction in average inventory when sharing stock-on-hand data. It is obvious from these results that an important reduction in average inventory can be achieved even in the case with seasonally varying demand by letting the supplier share the customers' stock-on-hand data. The reduction is the same size as for the even demand scenario. The influence of non-information sharing customers is the same as in the even demand scenario.

The simulation shows that sharing information about customers' planned orders causes significant increases in inventory. This outcome is in principle similar to the results achieved for the scenario with even demand. The increase is, however, much bigger. An explanation is that the seasonal variation in demand reinforces the variations in the sum of planned customer orders compared to the scenario with even demand.

Appendix A.2 displays the corresponding results when the customers’ replenishment orders equal ten days' average demand. No changes in inventory levels were found when customers' forecasts and point-of sales data are shared, as was the case for a five days' average demand.

As in the scenario with even demand and shared stock-on-hand information, a comparison between Tables 5 and Appendix A.2 reveals that the reduction in inventory becomes much bigger when the customer replenishment order quantities increase. This can be expected for the same reasons outlined above. The increase in inventory levels when sharing information 
Full reference to this article: Jonsson, P. and Mattsson, S-A. (2013). "The value of sharing planning information in supply chains”. International Journal of Physical Distribution and Logistics Management, Vol. 43, No. 4, pp. 282-299. DOI: http://dx.doi.org/10.1108/IJPDLM-07-2012-0204

about planned orders is again basically independent of the size of the customers' replenishment orders.

\section{Demand scenario 3: Promotional type of demand}

The scenario with promotional type of demand is characterised by an even demand with random variations interspersed with periods of increased demand due to promotional activities. As displayed in Table 6 (orders equal to five days' demand), no significant change in average inventory is achieved when the supplier has access to the customers' point-of-sales data compared to the case with no information sharing. This can be expected since neither supplier forecasts based on historical deliveries nor supplier forecasts based on point-of-sales can predict sudden increases in demand. The only difference is basically that information about an increase in demand will be more delayed when historical demand is used to forecast rather than point-of-sales data. The short replenishment lead time (two days in this study) is obviously too short to create any significant Forrester (1961) type of bullwhip effect. This corresponds to the conclusions of Lee et al. (2000) that the underlying demand processes and the lead times have a significant impact on the magnitude of inventory reductions associated with sharing point-of-sales data.

Basically no changes in inventory were found when sharing stock-on-hand data. This is opposite to the scenarios with even and seasonal demand, where very significant reductions are achieved. The reason is that the increase in demand due to promotional activities is not known in advance.

Table 6. Changes in capital tied up in inventory in per cent for various information types (Promotional demand, customer replenishment order quantities $=5$ days' average demand)

\begin{tabular}{|l|c|c|c|c|c|c|}
\hline \multirow{2}{*}{$\begin{array}{l}\text { Type of shared } \\
\text { information }\end{array}$} & \multicolumn{6}{|c|}{ Number of customers in the distribution network } \\
\cline { 2 - 7 } & 3 & 6 & 9 & 18 & $9+20 \%$ & $9+40 \%$ \\
\hline Forecast & $\mathbf{- 3 6 . 3}$ & $\mathbf{- 3 8 . 6}$ & $\mathbf{- 4 1 . 7}$ & $\mathbf{- 4 1 . 8}$ & $\mathbf{- 3 9 . 4}$ & $\mathbf{- 3 6 . 9}$ \\
\hline Point-of-sales & 0.1 & 0.1 & 0.2 & 0.0 & -0.3 & -0.2 \\
\hline Stock-on-hand & 0.3 & $\mathbf{2 . 8}$ & -0.1 & 0.3 & 0.5 & 0.8 \\
\hline Planned orders & $\mathbf{- 1 4 . 2}$ & $\mathbf{- 1 2 . 4}$ & $\mathbf{- 1 5 . 7}$ & $\mathbf{- 1 4 . 9}$ & $\mathbf{- 1 2 . 7}$ & $\mathbf{- 1 2 . 0}$ \\
\hline
\end{tabular}

Note: The figures represent changed inventory level mean values (in percentage) compared to the baseline scenario without information sharing. Bold means are significantly different $(\mathrm{p}<0.05)$ compared to the baseline scenario without information sharing.

Unlike the scenarios with even demand and seasonal variation in demand, significant reductions in average inventory are achieved when forecasts and planned order information are shared with customers. This can be expected since promotional influences on customer demand from a supplier point of view represent a non-stationary condition that cannot be forecast by the supplier. By using customer forecasts or planned orders from the customers, the supplier can base its inventory replenishment decisions on this information instead of historical sales. These findings support Angulo et al. (2004) who argue that sharing forecasts should primarily be applied when demand is non-stationary. They are also in line with Kaipia and Hartiala (2006) who argue that sharing forecast information is more valuable when the customers' forecasts are more accurate than the supplier's.

The results when the replenishment quantities correspond to ten days' average demand (Appendix A.3) are quite similar to the five days' demand case (Table 6). It can be noted, however, that the reduction in inventory is a little larger when the replenishment quantities are 
Full reference to this article: Jonsson, P. and Mattsson, S-A. (2013). "The value of sharing planning information in supply chains”. International Journal of Physical Distribution and Logistics Management, Vol. 43, No. 4, pp. 282-299. DOI: http://dx.doi.org/10.1108/IJPDLM-07-2012-0204

smaller in the case with shared forecasts. This can be expected since a consequence of using small replenishment quantities is that the inventory levels adjust themselves faster than when bigger replenishment quantities are used. When larger order quantities are used, it takes longer for the customers' level of inventory to adjust to the increased demand. These delays decrease the echelon stock and reduce the discrepancy in updating the echelon stock and the demand during lead time. The effect is the opposite when demand decreases after the promotional period. Big customer inventories contribute to a faster adjustment of the supplier's inventory when the end customer demand decreases.

\section{Conclusions}

Table 7 summarises the findings regarding the value of information sharing with medium to high customer order frequency and two-tier supply chains with relatively short lead times.

Table 7. Resulting changes in inventory due to various types of information sharing

\begin{tabular}{|l|c|c|c|}
\hline \multirow{2}{*}{$\begin{array}{l}\text { Type of shared } \\
\text { information }\end{array}$} & \multicolumn{3}{|c|}{ Demand scenario } \\
\cline { 2 - 4 } & 1. Even demand & 2. Seasonal variation & 3. Promotional demand \\
\hline Customer forecasts & No change & No change & Major reduction \\
\hline Point-of-sales & No change & No change & No change \\
\hline Stock-on-hand & Major reduction & Major reduction & No change \\
\hline Planned order & Some increase & Major increase & Major reduction \\
\hline
\end{tabular}

The following general conclusions are drawn:

1) The value of information sharing differs depending on whether demand is stationary or non-stationary. 2) Sharing stock-on-hand data is valuable when demand is stationary (with both random and cyclical variations). 3) Sharing customer forecast and planned order information is valuable when demand is non-stationary. Due to system nervousness created by the Burbidge type of bullwhip effects, inventories increase rather than decrease when sharing planned order information when the demand is stationary. 4) Sharing point-of-sales data has no value, regardless of demand type. 5) With stationary demand, the value of information sharing is in general larger when there are fewer customers, with a larger proportion of all customers involved in information sharing, and larger order batch sizes (i.e. when the bullwhip effect is significant). For non-stationary demand, this order batch size effect does not exist. There are significant reductions in inventories with stationary demand when sharing only stock-on-hand data with a limited number of big customers and no information sharing with small customers. This indicates that it may be valuable to share information with only a limited number of large customers, which is often the most practical solution for information sharing.

The fact that sharing point-of-sales data did not result in any inventory reduction, no matter the demand pattern, distribution structure or order quantity may seem surprising, because the importance of sharing point-of-sales data is generally emphasised in supply chain literature. The main explanation is that our study focuses on a two-stage distribution network with a replenishment lead time of the customer inventory of two days (which is a very common distribution network set-up in practice). For distribution networks with considerably longer lead times and more echelons, the value of sharing point-of-sales data could be expected to be higher, especially in non-stationary demand situations. 
Full reference to this article: Jonsson, P. and Mattsson, S-A. (2013). "The value of sharing planning information in supply chains”. International Journal of Physical Distribution and Logistics Management, Vol. 43, No. 4, pp. 282-299. DOI: http://dx.doi.org/10.1108/IJPDLM-07-2012-0204

For demand with a more or less stationary pattern, the only shared information type resulting in reduced inventory was stock-on-hand data and the use of multi-echelon stock models. Sharing and using stock-on-hand data was valuable in all tested situations. This study thus indicates that it should be valuable to use multi-echelon stock models to improve inventory management performance when demand is stationary. Multi-echelon stocks have been more heavily emphasised in the analytical literature than in the empirical literature. It should therefore be interesting to investigate the potential of multi-echelon stocks in future empirical studies and practice.

The study also showed that there is no value in sharing customer forecasts when demand is stationary. Sharing of planned orders resulted in negative performance because of amplified bullwhip effects. This indicates that information sharing may even have a negative performance impact if it is used without understanding of when to share and how to use the information. Very little research has studied the negative effects of information sharing or the ability to use information.

For demand that is non-stationary our findings were in line with and verified the conclusions of previous studies. Customer forecasts and planned orders give the suppliers future-oriented demand-related information and help them predict demand variations of the non-stationary type. Point-of-sales and stock-on-hand data, on the other hand, do not contain any information about future demand and therefore do not yield any value when demand is non-stationary.

These conclusions fill some gaps in the information sharing literature and should be relevant to the wider collaborative planning and supply chain integration fields, for example, when developing constructs and defining contextual dimensions. They should also have direct managerial implications as a guide for developing information sharing strategies.

The study's limitations relate to the comparatively short delivery lead times from supplier to the customers, and the small order quantities. Longer lead times should influence the results and conclusions concerning the seasonal demand scenario and the promotional demand scenario due to Forrester type of bullwhip effects. Also, the larger the order quantities, the more information about changes in current demand will be delayed when information sharing is not used. Larger order quantities will thus favour the various types of information sharing in environments with non-stationary demand. In the non-stationary scenario used here, all customers' promotional are conducted in the same time periods. If the campaigns were not run in parallel, the non-stationary demand pattern would be evened out.

This study focused on a distribution network where both customers and suppliers use decentralised re-order point $(\mathrm{R}, \mathrm{Q})$ methods. The conclusions are consequently valid for similar distribution networks and inventory models. The different demand scenarios used in the simulation study are representative of common demand patterns in practice, and the lead times are representative of common intracontinental distribution lead times. The demand scenarios should, consequently, allow for quite general conclusions in cases of medium to high customer order frequency, but not for slow-moving items. The lead times should allow for generalization to common intracontinental supply chains, but not to supply chains with very long lead times. Further simulation studies in other demand and supply contexts and with other inventory control models are required to find out to what extent the findings of this study are representative and generalizable. 
Full reference to this article: Jonsson, P. and Mattsson, S-A. (2013). "The value of sharing planning information in supply chains”. International Journal of Physical Distribution and Logistics Management, Vol. 43, No. 4, pp. 282-299. DOI: http://dx.doi.org/10.1108/IJPDLM-07-2012-0204

\section{References}

Ahuhilal, L., Rabadi, G., Sousa-Poza, A. (2006), "Supply chain inventory control: a comparison between JIT, MRP and MRP with information sharing using simulation”, Engineering Management Journal, Vol. 18, No. 2, pp. 51-57.

Angulo, A., Nachtmann, H.,Waller, M. (2004), “Supply chain information sharing in a vendor managed inventory partnership”, Journal of Business Logistics, Vol. 25, No. 1, pp. 101-120.

Aviv, Y. (2001), "The effect of collaborative forecasting on supply chain performance”, Management Science, Vol. 47, No. 10, pp. 1326-1343.

Axsäter, S., Rosling, K. (1993),“Installation vs. echelon stock policies for multilevel inventory control”, Management Science, Vol. 39, No. 10, pp. 1274-1280.

Bagchi, U., Haya, J.,Ord, J. (1984), “Concepts, theory and techniques: modeling demand during lead time”, Decision Science, Vol. 15, pp. 157-176.

Barratt, M. and Oke, A. (2007), “Antecedents of supply chain visibility in retail supply chains: a resource-based theory perspective”, Journal of Operations Management, Vol. 25, pp. 1217-1233.

Bourland, K., Powel, S., Pyke, D. (1996), “Exploiting timely demand information to reduce inventories”, European Journal of Operational Research, Vol. 92, pp. 239-253.

Burbidge, J. (1991), "Period batch control (PBC) with GT - the forward from MRP”, Paper presented at the BPCIS Annual Conference, Birmingham.

Cachon, G., Fisher, M. (2000), "Supply chain inventory management and the value of shared information”, Management Science, Vol. 46, No. 8, pp. 1032-1048.

Chen, F. (1998), "Echelon reorder points, installation reorder points, and the value of centralized demand information”, Management Science, Vol. 44, No. 12, pp. 221-234.

Chen, F., Drezner, Z., Ryan, J., Simchi-Levi, D. (2000), ”Quantifying the bullwhip effect in simple supply chains: the impact of forecasting, lead times, and information”, Management Science, Vol. 46, No. 3, pp. 436-443.

Croson, R., Donohue, K. (2003), "Impact of POS data sharing on supply chain management: an experimental study”, Production and Operations Management, Vol. 12, No. 1, pp. 1-11.

Danese, P. (2007),’Designing CPFR collaborations: insights from seven case studies”, International Journal of Operations \& Production Management, Vol. 27, No. 2, pp. 181-204.

Devaraj, S., Krajewski, L., Wei, J.C. (2007), “Impact of e-business technologies on operational performance: the role of production information in the supply chain", Journal of Operations Management, Vol. 25, No. 6, pp. 1199-1216.

Flynn, B., Huo, B., Zhao, X. (2010), “The impact of supply chain integration on performance: a contingency and configuration approach”, Journal of Operations Management, Vol. 28, pp. 58-71.

Fogarty, D., Blackstone, J., Hoffman, T. (1991), Production and inventory management, South-Western Publishing, New York.

Sahin, F. and Robinson, P. (2002), "Flow coordination and information sharing in supply chains: Review, implications, and directions for future research”. Decision Sciences, Vol. 33, No. 4, pp. 505-536.

Forslund, H. and Jonsson, P. (2007), "The impact of forecast information quality on supply chain performance”, International Journal of Operations and Production Management, Vol. 27, No. 1, pp. 90-107. 
Full reference to this article: Jonsson, P. and Mattsson, S-A. (2013). "The value of sharing planning information in supply chains”. International Journal of Physical Distribution and Logistics Management, Vol. 43, No. 4, pp. 282-299. DOI: http://dx.doi.org/10.1108/IJPDLM-07-2012-0204

Forrester, J. (1961), Industrial dynamics, MIT Press, Cambridge, MA.

Frohlich, M., Westbrook, R. (2001), “Arcs of integration: an international study of supply chain strategies”, Journal of Operations Management, Vol. 19, pp. 185-200.

Gilbert, K. (2005), “An ARIMA supply chain model”, Management Science, Vol. 51, No. 2, pp. 305-310.

Huang G.Q., Lau, S.K. and Mak, K.L. (2003), “The impacts of sharing production information on supply chain dynamics: a review of the literature”, International Journal of Production Research, Vol. 41, No. 7, pp. 1483-1517.

Ketzenberg, M., Rosenzweig, E., Marucheck, A., Metters, R. (2007), “A framework for the value of information in inventory management”, European Journal of Operational Research, Vol. 182, pp. 1230-1250.

Kaipia, R., Hartiala, H. (2006), "Information sharing in supply chains: five proposals on how to proceed”, International Journal of Logistics Management, Vol. 17, No. 3, pp. 377-393.

Lee, H., Padmanabhan, V., Whang, S. (1997), "Information distortion in a supply chain: the bullwhip effect”, Management Science, Vol. 43, No. 4, pp. 633-640.

Lee, H., So, K., Tang, C. (2000), “The value of information sharing in a two-level supply chain”, Management Science, Vol. 46, No. 5, pp. 626-643.

Martin, A. (1983), DRP: Distribution resource planning, The Oliver Wight Companies.

Mishra, B., Raghunathan, S., Yue, X. (2009), "Demand forecast sharing in supply chains”, Production and Operations Management, Vol. 18, No. 2, 152-166.

Moinzadeh, K. (2002), “A multi-echelon inventory system with information exchange”, Management Science, Vol. 48, No. 3, pp. 414-426.

Persson, F.,Olhager, J. (2002) "Performance simulation of supply chain designs", International Journal of Production Economics, Vol.77, No. 3, pp. 231-245.

Seifert, D. (2003) Collaborative Planning, Forecasting, and Replenishment. American Management Association, New York.

Sezen, B. (2008),"Relative effects of design, integration and information sharing on supply chain performance”, Supply Chain Management: An International Journal, Vol. 13, No. 3, pp. 233-240.

Skjoett-Larsen, T., Thernøe, C., Andresen, C. (2003),"Supply chain collaboration: theoretical perspectives and empirical evidence", International Journal of Physical Distribution \& Logistics Management, Vol. 33, No. 6, pp. 531-549.

Småros, J., Lehtonen, J-M., Appelqvist, P., Holmström, H. (2003), “The impact of increasing demand visibility on production and inventory control efficiency”, International Journal of Physical Distribution \& Logistics Management, Vol. 33, No. 4, pp. 336-354.

Stank, T., Keller, B., Daugherty, P. (2001), "Supply chain collaboration and logistical service performance”, Journal of Business Logistics, Vol. 22, No. 1, pp. 29-48.

Van Donselaar, K., Gubbels, B. (2002), "How to release orders in order to minimize inventory and system nervousness?”, International Journal of Production Economics, Vol. 78, pp. 335-343.

Vigtil, A. (2007),"Information exchange in vendor managed inventory”, International Journal of Physical Distribution \& Logistics Management, Vol. 37, No. 2, pp. 131-147. Williams, B. and Waller, M. (2010), “Creating order forecast: point-of-sales or order history?”, Journal of Business Logistics, Vol. 31, No. 2, pp. 231-251. 
Full reference to this article: Jonsson, P. and Mattsson, S-A. (2013). "The value of sharing planning information in supply chains”. International Journal of Physical Distribution and Logistics Management, Vol. 43, No. 4, pp. 282-299. DOI: http://dx.doi.org/10.1108/IJPDLM-07-2012-0204

Yu, Z., Yan, H., Cheng, T. (2000), "Benefits of information sharing with supply chain partnerships”, Industrial Management and Data System, Vol. 101, No. 3, pp. 114-119.

Zhao, X., Xie, J. (2002), "Forecasting errors and the value of information sharing in supply chains”, International Journal of Production Research, Vol. 40, No. 2, pp. 311-335.

Zhou, H. and Benton W.C. (2007), "Supply chain practice and information sharing”, Journal of Operations Management, Vol. 24, pp. 1348-1365. 
Full reference to this article: Jonsson, P. and Mattsson, S-A. (2013). "The value of sharing planning information in supply chains”. International Journal of Physical Distribution and Logistics Management, Vol. 43, No. 4, pp. 282-299. DOI: http://dx.doi.org/10.1108/IJPDLM-07-2012-0204

\section{Appendix A}

Table A.1 Changes in capital tied up in inventory in per cent for various information types (Even demand and customer replenishment order quantities $=10$ days' average demand)

\begin{tabular}{|l|c|c|c|c|c|c|}
\hline \multirow{2}{*}{$\begin{array}{l}\text { Type of shared } \\
\text { information }\end{array}$} & \multicolumn{6}{|c|}{ Number of customers in the distribution network } \\
\cline { 2 - 7 } & 3 & 6 & 9 & 18 & $9+20 \%$ & $9+40 \%$ \\
\hline Forecast & 0.0 & 0.0 & 0.1 & -0.2 & 0.0 & 0.3 \\
\hline Point-of-sales & -0.2 & 0.2 & 0.1 & -0.2 & -0.3 & 0.1 \\
\hline Stock-on-hand & $-\mathbf{3 0 . 0}$ & $-\mathbf{1 7 . 3}$ & $-\mathbf{1 0 . 0}$ & $-\mathbf{1 0 . 4}$ & $-\mathbf{6 . 1}$ & $-\mathbf{4 . 3}$ \\
\hline Planned orders & 0.5 & $\mathbf{3 . 9}$ & $\mathbf{4 . 3}$ & $\mathbf{5 . 1}$ & $\mathbf{5 . 5}$ & $\mathbf{5 . 0}$ \\
\hline
\end{tabular}

Note: The figures represent changed inventory level mean values (in percentage) compared to the baseline scenario without information sharing. Bold means are significantly different $(\mathrm{p}<0.05)$ compared to the baseline scenario without information sharing.

Table A.2 Changes in capital tied up in inventory in per cent for various information types (Seasonal demand and customer replenishment order quantities $=10$ days' average demand)

\begin{tabular}{|l|c|c|c|c|c|c|}
\hline \multirow{2}{*}{$\begin{array}{l}\text { Type of shared } \\
\text { information }\end{array}$} & \multicolumn{6}{|c|}{ Number of customers in the distribution network } \\
\cline { 2 - 7 } & 3 & 6 & 9 & 18 & $9+20 \%$ & $9+40 \%$ \\
\hline Forecast & -0.4 & -0.2 & 0.9 & -0.3 & -0.2 & 0.0 \\
\hline Point-of-sales & -0.3 & -0.2 & 0.8 & -0.2 & 0.0 & 0.0 \\
\hline Stock-on-hand & $-\mathbf{2 8 . 5}$ & $\mathbf{- 1 9 . 2}$ & $-\mathbf{1 1 . 5}$ & $-\mathbf{1 3 . 2}$ & $-\mathbf{9 . 5}$ & $\mathbf{- 8 . 2}$ \\
\hline Planned orders & $\mathbf{1 4 . 1}$ & $\mathbf{2 4 . 9}$ & $\mathbf{3 2 . 9}$ & $\mathbf{3 1 . 8}$ & $\mathbf{3 7 . 1}$ & $\mathbf{3 9 . 3}$ \\
\hline
\end{tabular}

Note: The figures represent changed inventory level mean values (in percentage) compared to the baseline scenario without information sharing. Bold means are significantly different $(\mathrm{p}<0.05)$ compared to the baseline scenario without information sharing.

Table A.3 Changes in capital tied up in inventory in per cent for various information types (Promotional demand, customer replenishment order quantities $=10$ days' average demand)

\begin{tabular}{|l|c|c|c|c|c|c|}
\hline \multirow{2}{*}{$\begin{array}{l}\text { Type of shared } \\
\text { information }\end{array}$} & \multicolumn{6}{|c|}{ Number of customers in the distribution network } \\
\cline { 2 - 7 } & 3 & 6 & 9 & 18 & $9+20 \%$ & $9+40 \%$ \\
\hline Forecast & $\mathbf{- 1 9 . 8}$ & $\mathbf{- 3 1 . 5}$ & $\mathbf{- 3 6 . 7}$ & $\mathbf{- 3 6 . 6}$ & $\mathbf{- 3 6 . 5}$ & $\mathbf{- 3 4 . 5}$ \\
\hline Point-of-sales & -0.3 & 0.0 & 0.0 & -0.3 & 0.0 & -0.3 \\
\hline Stock-on-hand & $\mathbf{3 . 8}$ & -0.3 & 0.8 & 1.5 & 0.2 & 1.5 \\
\hline Planned orders & $\mathbf{- 7 . 7}$ & $\mathbf{- 8 . 3}$ & $\mathbf{- 1 2 . 1}$ & $\mathbf{- 1 1 . 1}$ & $\mathbf{- 1 1 . 9}$ & $\mathbf{- 1 0 . 2}$ \\
\hline
\end{tabular}

Note: The figures represent changed inventory level mean values (in percentage) compared to the baseline scenario without information sharing. Bold means are significantly different $(\mathrm{p}<0.05)$ compared to the baseline scenario without information sharing. 